\title{
ベクトルマテリアルの材料科学と応用
}

\author{
堀内 尚紘, 和田 徳雄, 中村 美穂, 永井覀希子, 山下 仁大 \\ 東京医科歯科大学生体材料工学研究所 無機材料分野, 广 101-0062 千代田区神田駿河台 2-3-10.
}

\section{Material Science and Applications of Vector Materials}

\author{
Naohiro Horiuchi, Norio Wada, Miho Nakamura, Akiko Nagai and Kimihiro Yamashita \\ Institute of Biomaterial \& Bioengineering, Tokyo Medical and Dental University, \\ 2-3-10 Kanda-Surugadai, Chiyoda-ku, Tokyo 101-0062, Japan.
}

Received ebruary 3, 2011

\begin{abstract}
SYNOPSIS
We define a vector material as one can manipulate surroundings or circumstance of oneself. Especially, the interaction effect between surface charges and materials based on the electric force is called termed as electrovector effect. In this report, we demonstrated that fabrication and development of electrets which have electrovector effect. The electrets with hydroxyapatite (HAp) have the electrovector effect which increases the ability to promote bone regeneration (osteoanagenesis). In order to reveal the working and mechanism of electrovector effect on biomineralization in vivo, we study electrovector effect of crystal growth on the electret substrates. We found that surface charges on the substrates promoted precipitation of HAp in simulated body fluid (SBF), and influenced the morphology of calcite thin film growth on substrates with HAp and yittria stabilized zirconia (YSZ) .
\end{abstract}

KEY WORDS

vector materials, hydroxyapatite, calcite, yittria-stabilized zirconia, electret

1 ベクトルマテリアル

人体は外界に対して“閉じた系”を形成しているとみなす ことができる.同様に, 物体内部に形成された界面も“閉じ た系”であると考えられる．この閉じた系の内部の反応を何 らかの刺激によって制御することを考えると, 外部より電場, 磁場を印加する, または放射線や超音波など照射するという 手段が先ず考えられる(Fig.1 (A)). しかし, この場合, 外部か らの刺激は, 所望の場所以外の場所に二次的な望ましくない 效果を与えてしまう可能性がある。一方, 閉じた系の内部で 周辺に対してのみ影響を与えることができる物質ならば, こ のような状況下で非常に有用であろう(Fig.1 (B)). 例えば磁石 (マグネット)は外部からのエネルギ一供給が不要であり,ま たその近傍にのみ磁力を作用させることができる．また，生 体はイオンやたんぱく質など電解質によって構成されている ため, 静電場が生体内部への刺激として非常に有用であるこ とは容易に想像できる。ところが, 外部からの静電場の印加 は, 細胞や組織を破壞してしまう。この問題は, 生体内部に

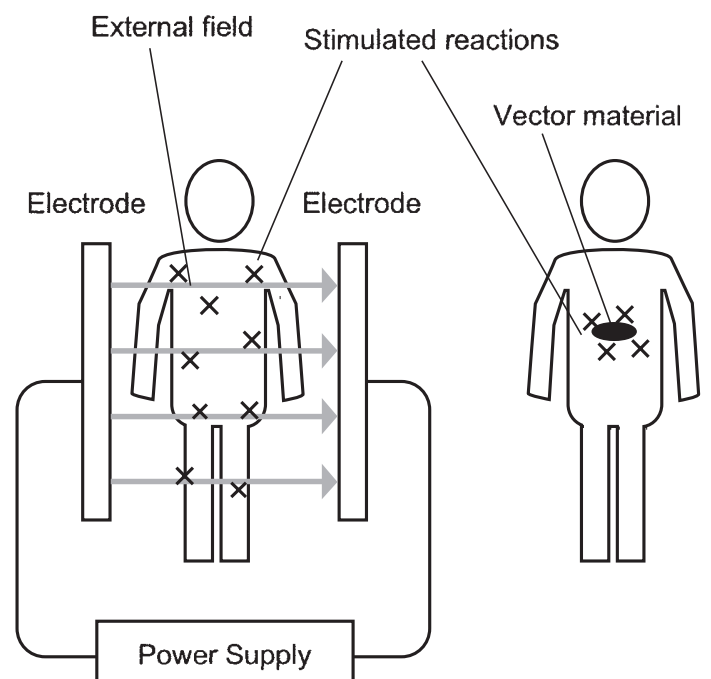

A

Fig.1 Stimulated reactions induced by external field and vector material. 
局所的に静電場を形成できるエレクトレットを用いることで 解決できる、筆者らは，生体親和性に優れたハイドロキシア パタイトをエレクトレット化することに成功し, さらにその エレクトレットを用いて生体内部の局所的な反応制御に成功 した ${ }^{1-6)}$.

上記のような材料の周辺の物質・物体を制御する材料のこ とをべクトルマテリアルと定義した. ベクトル[vector]は, 一 般的には，大きさと方向を持った量を表す数学的用語，また はウイルスの担体を意味する分子生物学用語であるが, これ に加えて「電波によって物体を誘導する」という意味を持つ. これに基づき筆者らは,「材料によって周辺物質あるいは生物 を操る(マニピュレート)すること」と解釈を加え, ベクトル マテリアルを定義し，さらにその効果をベクトル効果と呼ぶ ことにした. ベクトルマテリアルのうち特に静電気力により による効果をエレクトロベクトルマテリアルと呼ぶ.

ベクトルマテリアルの代表例をTable 1に示す.エレクトレッ ト，マグネットに加えて放射性物質もベクトルマテリアルで ある.放射性物質をガラス中に分散させたベクトルマテリアル は, 癌治療に応用されている. バイオガラスや $\beta$ リン酸三力 ルシウムは体内において高い溶解性を持ち, 高い骨伝導能を 有する ${ }^{7.8)}$.これは化学べクトルマテリアルと呼ぶことができる.

本報告では, まず次節において, エレクトレットの創製と, 生体内においてのベクトル効果として, ハイドロキシアパタ イト (HAp) エレクトレットによる骨伝導能向上効果, 言い換

Table 1 Examples of vector materials.

\begin{tabular}{|c|c|c|}
\hline Vector materials & $\begin{array}{l}\text { Driving } \\
\text { force }\end{array}$ & $\begin{array}{l}\text { Possible examples/ } \\
\text { materials }\end{array}$ \\
\hline $\begin{array}{l}\text { Electrovector } \\
\text { material }\end{array}$ & $\begin{array}{l}\text { Electrostatic } \\
\text { force }\end{array}$ & Hydroxyapatite \\
\hline $\begin{array}{l}\text { Magnetrovector } \\
\text { material }\end{array}$ & $\begin{array}{l}\text { Magnetic } \\
\text { force }\end{array}$ & Nd-Fe-B magnet \\
\hline $\begin{array}{l}\text { Chemicovector } \\
\text { material }\end{array}$ & $\begin{array}{l}\text { Chemical } \\
\text { property }\end{array}$ & $\begin{array}{l}\text { Bioglass, } \\
\text { Tricalcium phosphate }\end{array}$ \\
\hline Biovector material & $\begin{array}{l}\text { Biological } \\
\text { property }\end{array}$ & $\begin{array}{l}\text { Cells with ceramic } \\
\text { scaffold }\end{array}$ \\
\hline $\begin{array}{r}\text { Radioactivevector } \\
\text { material }\end{array}$ & $\begin{array}{l}\text { Radioactive } \\
\text { property }\end{array}$ & YAS glass \\
\hline $\begin{array}{l}\text { Thermovector } \\
\text { material }\end{array}$ & $\begin{array}{l}\text { Thermal } \\
\text { property }\end{array}$ & Ferrite deposited glass \\
\hline Optovector material & $\begin{array}{l}\text { Optical } \\
\text { property }\end{array}$ & $\begin{array}{l}\text { Phosphorescent } \\
\text { material }\end{array}$ \\
\hline $\begin{array}{l}\text { Mechanovector } \\
\text { material }\end{array}$ & $\begin{array}{l}\text { Mechanical } \\
\text { property }\end{array}$ & Shape memory alloy \\
\hline
\end{tabular}

えるとバイオミネラリゼーションへのベクトル効果を紹介す る. 第 3 節以降では，このバイオミネラリゼーションへのベ クトル効果のメカニズム理解の基礎として, 結晶成長におけ るエレクトロベクトル効果を研究したその成果を紹介する. 擬似体液(SBF) 用いた HApエレクトレット基板上での水酸 アパタイトの結晶成長およびHAp, イットリア安定化ジルコ ニア(YSZ)エレクトレット基板上でポリアクリル酸(PAA)の 添加・無添加の下でのカルサイト (炭酸カルシウムの多形の 一つで, 常温常压下で最も安定な結晶相)の結晶成長につい て得られたエレクトロベクトル効果の成果について紹介する.

\section{2 エレクトレットの創製と生体マニュピュレーション}

ハイドロキシアパタイト $\left(\mathrm{Ca}_{5}\left(\mathrm{PO}_{4}\right)_{3} \mathrm{OH} ; \mathrm{HAp}\right)$ は優れた生体 親和性を有すると同時に, 電気的特性においても重要な性質 を持っている ${ }^{9,10)}$. HAp はプロトン伝導体であり, HAp 中の プロトンは外部電圧の印加によって移動する. その結果HAp 中にプロトン濃度分布の勾配が形成(空間電荷分極の形成)さ れ, HApはエレクトレット (electret) となる. エレクトレット は, 磁力を有するマグネット (magnet)に対して, 静電気力を 有する物質に対して命名された. マグネットが古くから多方 面に利用されているのに比べ, エレクトレットの利用は極め て少ない。この理由としては，静電気力を長期にわたって維 持できる高品質なエレクトレットの希少性が一因であると考 えられる.この点から HApの持つ分極可能であるという性質 は非常に重要である。

HApの分極は, 中高温での電圧印加によってプロトンを移 動させることで形成する. HAp の焼結体を $300^{\circ} \mathrm{C}$ に保持し, $1 \mathrm{kV} \cdot \mathrm{cm}^{-1}$ の直流電界を一定時間印加し, 電界を保持したまま 室温まで冷却することで分極HApを得ることができる. 電圧 処理時, 電源負極側に接している面を P 面 (Positively charged surface), 正極側に接している面を $\mathrm{N}$ 面 (Negatively charged surface) と呼ぶ(Fig.2). また, 分極していない面のことを 0 面と 呼ぶ，分極状態の評価は熱刺激脱分極電流 (TSDC; Thermally stimulated depolarization current)の測定によって行うことがで きる.昇温過程での脱分極による緩和電流を観測することで, 蓄積電荷量, 分子運動の活性化工ネルギーを求めることがで

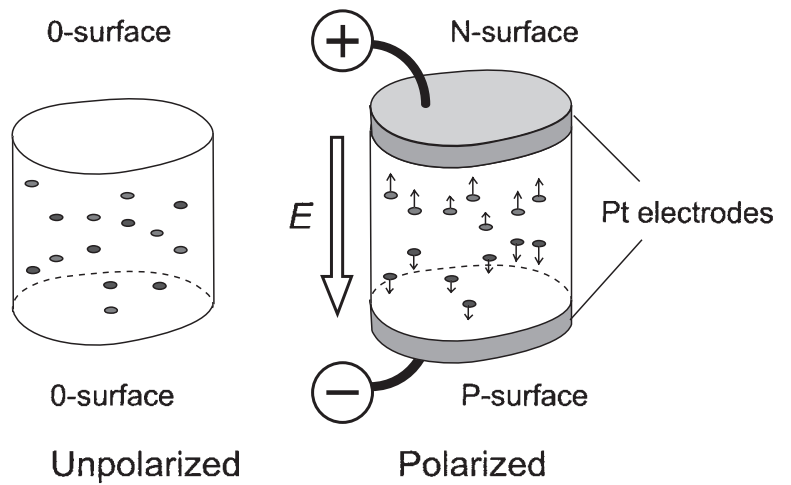

Fig.2 Schematic illustration of electrical polarization procedure and nomenclature of polarized and unpolarized surfaces. 
きる. Fig.3にTSDC測定の一例を示した. 分極処理時の印加 電圧の増加に伴い緩和電流が増加している.

分極によって形成したHApエレクトレットのエレクトロベ クトル効果は, 骨再生を促進する。これは, ビーグル犬を用 いた動物実験により明らかになった。ビーグル犬の大腿骨に 分極および未分極HApを埋入した. 埋入したセラミックス面 と皮質骨切削面の間隔は $0.2 \sim 0.3 \mathrm{~mm}$ に固定した. 7 日後，試 料を埋入した骨を取り出し，観測した。 $\mathrm{N}$ 面においては，厚 さ $0.02 \mathrm{~mm}$ の層状の新生骨が形成し，さらにこの層状新生 骨の反対側では, 陽性の骨芽細胞と思われる平面状の細胞群 が観察された. (Fig.4 (A)) 平板上の細胞は, N面対向して位置 する皮質骨切削面の上にも観察された。P面近傍では，直接 接合している新生骨は観察されなかったが, 骨芽細胞と思わ れる細胞に取り囲まれた類骨様組織が観察された(Fig.4 (B)). 0 面近傍においては，皮質骨切削面とセラミックス面の間は 繊維状組織に満たされているが, 新生骨の再生は観測できな かった (Fig.4(C)). 以上より，分極 HAp は表面の極性によっ て骨再生の様態に影響を与え, 分極処理を施さないHApに比 ベて高い骨伝導能を有することがわかった。

\section{3 エレクトレットによる電場と核形成理論}

誘電率 $\varepsilon$ の媒質中で厚さ $\xi$, 表面積 $S$ ，そして表面電荷密度 $\pm \sigma$ の板エレクトレット基板から $\mathrm{r}$ 離れた場所の電位 V は

$$
\mathrm{V}= \pm \xi \sigma \cos \omega / 4 \pi \varepsilon \mathrm{r}^{2}
$$

で与えられる， $\omega$ はエレクトレット内の電気双極子モーメン トの軸と位置ベクトル $\mathrm{r}$ とのなす角を表す。電場 $\mathrm{E} は-\partial V / \partial r$ で与えられるので，局所に作用することになる，この電場は 静電相互作用により帯電した面の基板近傍でイオン濃度を高 め，基板近傍で析出物に対して大きな過飽和度をもたらす. このことはHAp 基板上での HAp 結晶成長実験において, 分 極 $\mathrm{HAp}$ 基板の $\mathrm{N}$ 面近傍で $\mathrm{Ca}^{2+}$ イオンからの強い蛍光が共焦 点レーザ顕微鏡により観察されたことにより示された ${ }^{11}$.

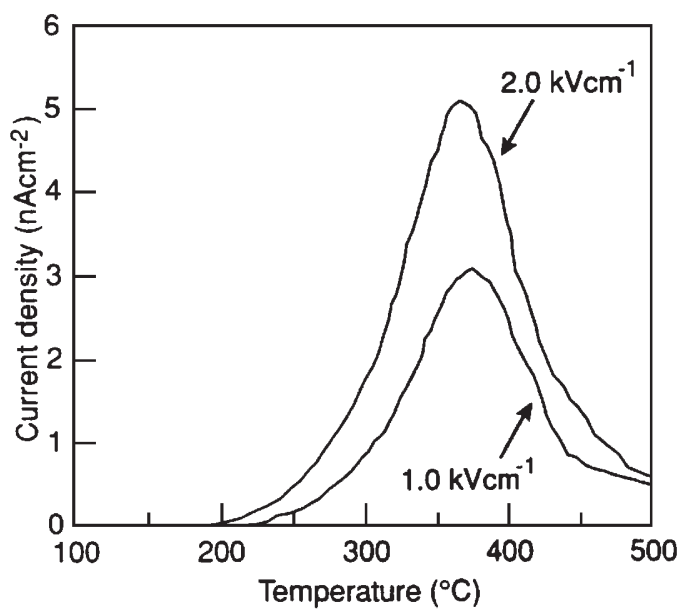

Fig.3 TSDC spectra of HA ceramics polarized at $300^{\circ} \mathrm{C}$.
ある不安定相の中に初めて安定相が形成されるときのエレ クトロベクトル効果を古典的核形成理論と電磁気学により考 察する.このときの安定相が 1 分子層でできた表面二次元核 と仮定すると, 大きさ $\mathrm{E}$ 電場の存在下での核形成の活性化 エネルギー $\Delta \mathrm{G}^{*}$ は

$$
\Delta \mathrm{G}^{*}=\beta^{2} \gamma^{2} /\left\{4 \mathrm{KT}\left(\operatorname{In} \alpha+\varphi \mathrm{E}^{2}\right)\right\}
$$

と表せる ${ }^{22}$. ここで $\beta$ は核の幾何学的形状に依存する定数, $\gamma$ は形成する核の表面エネルギー, $\mathrm{k}$ はボルツマン定数, Tは絶 対温度, $\alpha$ は母液の過飽和度, $\varphi$ は

$$
\begin{aligned}
& \varphi=-v\left[\left(1 / \varepsilon_{\mathrm{s}}-1 / \varepsilon_{\mathrm{l}}\right)\right. \\
& \left.+\left\{\left(\varepsilon_{\mathrm{s}}^{2}-1\right) / \varepsilon_{\mathrm{s}}-\left(\varepsilon_{\mathrm{s}}^{2}-1\right) / \varepsilon_{1}\right\} \sin ^{2} \theta / \mathrm{kT}\right]
\end{aligned}
$$

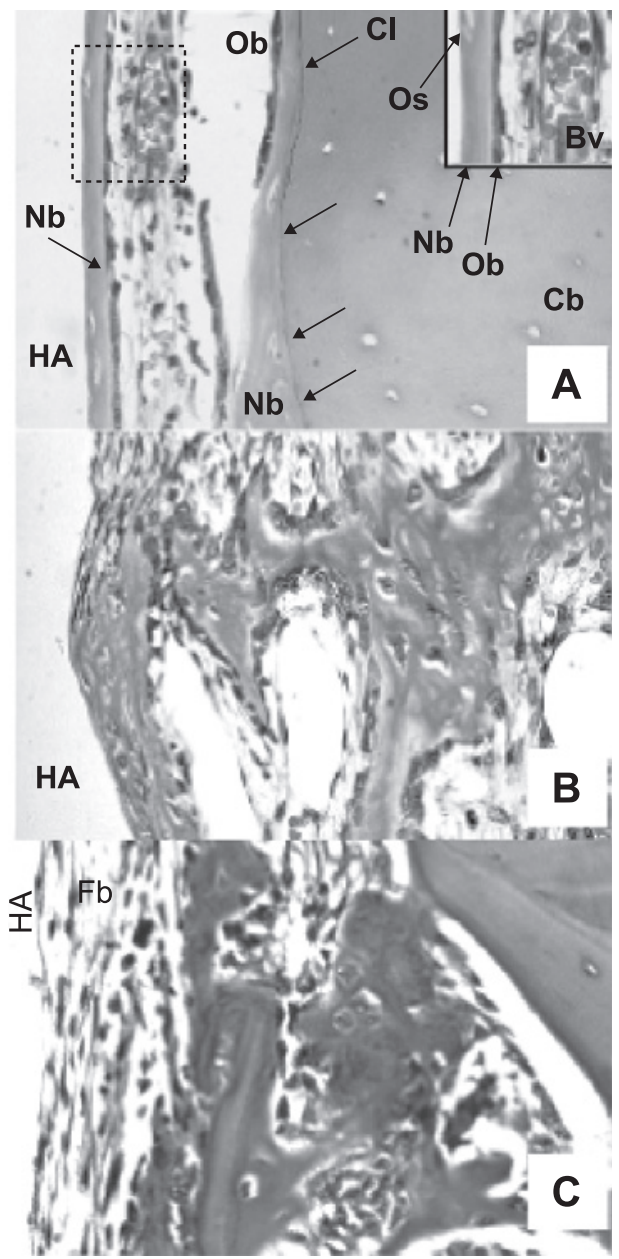

Fig.4 Cell morphologies extracted 7 days after implantation in wide gap between HAp ceramics (HA) and cortical bones (Cb) Insets are magnified views of rectangular frames of broken lines. (A) Newly formed bone (Nb) layer of $0.02 \mathrm{~mm}$ with osseous cells $(\mathrm{Os})$ and layered osteoblastic cells $(\mathrm{Ob})$ were in direct contact with $\mathrm{N}$-surfaces. Newly formed bones also were found on cortical bone with cement line. Many blood vessels (Bv) with erythrocytes occupied space among newly formed bones. (B) Osteoid tissues surrounded by osteoblastic cells in the vicinity of P-surface. (C) Osteoid tissues were found to be isolated from 0 -surface by dominant fibrin layers $(\mathrm{Fb})$ 
ここで， $\mathrm{v}$ は結晶を構成する分子の体積， $\varepsilon_{\mathrm{s}}$ は結晶核の誘電 率， $\varepsilon_{1}$ は水溶液の誘電率， $\theta$ は電場ベクトルと核形成した結 晶面とのなす角である. Fig.5にこの $\Delta \mathrm{G}^{*}$ と $\theta$ の間の関係を示 す。核形成のための活性化エネルギ一は，核形成する結晶面 と電場ベクトルのなす角が $90^{\circ}$ に近づくにつれて減少し, か つ, 核形成する結晶面の表面エネルギーが小さくなるにした がって減少することが分かる，一方，結晶核が作られる確率 $\mathrm{P}$ は $\mathrm{C}$ を定数として，P=C $\exp \left(-\Delta \mathrm{G}^{*} / \mathrm{kT}\right)$ と表される。した がって，エレクトレットによる電場の向きがエレクトレット 基板に対して垂直であることを考慮すると, 表面電場は表面 エネルギーが一番小さい結晶面の配向成長を促進する.

基板上での核形成は不均一核形成である。この核形成にお ける活性化エネルギーにとって接触角は重要な要素である. $\gamma$ を核の表面エネルギー， $\gamma_{1}$ を核と基板の表面エネルギー $\gamma_{2}$ を 基板の表面エネルギーとすると, これらの間には接蚛角を $\psi$ とするとヤングの式, $\gamma_{2}=\gamma_{1}+\gamma \cos \psi$ が成り立つ. 古典的核 形成理論によれば球冠状の核 $\left(\mathrm{V}_{\mathrm{m}}\right.$ : 分子容)が接触角 $\psi$ で析出 すると，核形成の活性化エネルギー $\Delta \mathrm{G}_{\mathrm{het}}^{*}$ は

$$
\Delta \mathrm{G}_{\mathrm{het}}^{*}=16 \pi \mathrm{V}_{\mathrm{m}}^{2} \gamma^{3} f(\psi) / 3\left(\Delta \mathrm{G}_{\mathrm{v}}\right)^{2}
$$

ここで, $\Delta \mathrm{G}_{\mathrm{v}}$ は結晶化の駆動力で結晶成分が環境相から結晶 相に組み込まれるときのギブスの自由エネルギーの変化, $f(\psi)$ は

$$
f(\psi)=\left(2-3 \cos \psi \theta+\cos ^{3} \psi\right) / 4
$$

で示され $0 \leqq f(\theta) \leqq 1$ の範囲で変化する $\psi$ の単調増加関数で ある. Fig.6に活性化エネルギー $\mathrm{G}_{\mathrm{het}}^{*}$ と接触角 $\psi$ の関係を示 す。すなわち，接触角の低下は活性化エネルギ一の減少を表 し，核形成は起こりやすくなる。

そこで, 分極・未分極のHApペレットとYSZペレット上の 水の接触角を測定した。未分極 HApペレット $(0$ 面)の接触角 は60であったが，分極 HAp ペレットのP面およびN面では ともに $35^{\circ} ま て ゙$ 下した ${ }^{13)}$. YSZペレットについても，0面では $101^{\circ}$ ，P面およびN面では， $80^{\circ}$ と $83^{\circ}$ に低下した，すなおち， 分極処理はこれらの基板上での核形成を起こしやすくする.

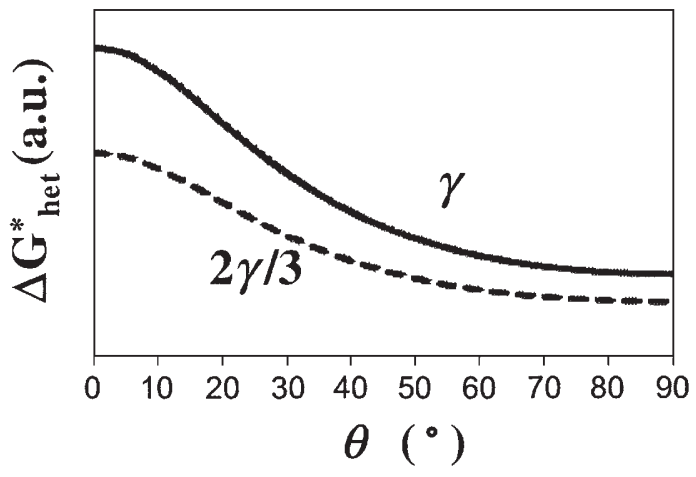

Fig.5 Variation of the critical free energy with the orientation of the electric field with respect to the surface of nucleation for various values of an interfacial tension: $(-)$ and $(\cdots)$ correspond to values of $\gamma$ and $2 \gamma / 3$, respectively.
4 分極アパタイトと分極イットリア安定化ジルコニアを 基板とした結晶成長実験

4.1 水酸アパタイトの結晶成長 ${ }^{11,14,15)}$

無機成分の混合比をヒトの体液とほぼ等しく調整した水溶 液, 擬似体液 $(\mathrm{SBF})$, の濃度を 1.5 倍した水溶液 $(1.5 \mathrm{SBF})$ の中 に分極・未分極HAp基板を浸漬して, 結晶成長実験を行った.

$1.5 \mathrm{SBF}$ 中に 24 時間浸漬後, 分極 HAp 基板の $\mathrm{N}$ 面と未分極 基板の面全体は結晶粒で覆われた。一方，P面では結晶粒は 確認できなかった。この結晶粒は骨類似結晶であることが X線回折測定および赤外分光測定結果から確認できた。分極・ 未分極基板上に析出した骨類似結晶の厚みを浸漬時間に対し てプロットして, 結晶成長速度を求めたところ, 未分極基板 上では $1 \mu \mathrm{m} / \mathrm{d}$ であるのに対し, $\mathrm{N}$ 面上では $6 \mu \mathrm{m} / \mathrm{d}$ に加速した. 一方, P面上では0面板上で得られた值より小さかった. また, 析出した薄膜を構成しているHAp 結晶のc 軸が分極基板に対 して垂直になっていた，すなわち，分極基板による電場べク トルに平行にHAp結晶は成長した. 共焦点レーザ顕微鏡観察 により分極 $\mathrm{HAp}$ 基板の $\mathrm{N}$ 面近傍で $\mathrm{Ca}^{2+}$ イオンからの蛍光の 高い強度を得たことにより $\mathrm{N}$ 面近傍での $\mathrm{Ca}^{2+}$ イオンの濃度の 増加が確認された。

HAp 多孔体 (多孔度 $75 \%$ ) と HAp 緻密体内に 1 本の細穴を

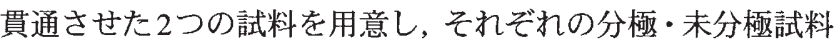
をSBFに浸漬させ, 細孔の表面からの深さによるその表面に 析出した HAp 量を調べた. HAp多孔体の場合は, 細孔の表面 の HAp 析出量は浸漬時間に比例して増加し, 0 面での膜厚と 比べると， $\mathrm{N}$ 面で厚く，P面では薄かった，その細孔の位置 が試料表面から梁くなるにしたがって薄膜の厚さは減少した. その膜厚の変化は 0 面では $2.6 \sim 0 \mu \mathrm{m}, \mathrm{N}$ 面では3.1 0.2 $\mu \mathrm{m}$, P面では2.5 0.2 $\mathrm{m}$ であった. HAp 緻密体の場合は, 未分極 試料内の HAp 結晶成長に比較して, 分極試料内の HAp 結晶 成長は貫通した細穴の位置に関係なく促進した。

HAp結晶析出に対するエレクトロベクトル効果はN面上で の結晶析出の促進, $\mathrm{P}$ 面上での抑制である. また, $\mathrm{c}$ 軸配向を 促進する. この現象の説明は, 分極基板による表面電場と

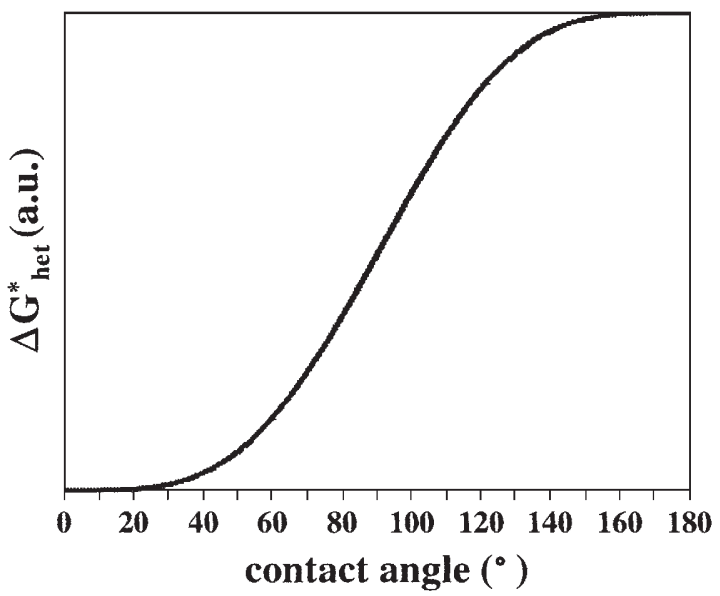

Fig.6 Change of the critical free energy of heterogeneous nucleation as a function of contact angle. 
SBF中のイオンまたはイオングループとの相互作用により説 明できる. SBF 中では， N 面近傍にカチオンが， P 面近傍に はアニオンが静電的に引きよせられる. 骨類似結晶核形成に おいてカルシウムイオンが核形成を促進するので，0 面に比 較して $\mathrm{N}$ 面近傍でカルシウムイオン濃度が高 $<, \mathrm{P}$ 面近傍で 低くなることで， $\mathrm{N}$ 面上での結晶成長速度の増大， P 面上で 結晶成長速度の減少が生じたと考えられる。

4.2 炭酸カルシウムの結晶成長

炭酸カルシウムの結晶成長実験は, 水溶液成長で一般的に 用いられている $\mathrm{CaCl}_{2}-\left(\mathrm{NH}_{4}\right)_{2} \mathrm{CO}_{3}$ 実験系を用いた ${ }^{16-23)}$. 使用 した基板は HAp とYSZの分極・未分極基板である．可溶性 高分子を添加した場合のエレクトロベクトル効果も検討する ためにポリアクリル酸(PAA)を添加した. デシケータの中の ビ一カーに $\mathrm{CaCl}_{2}$ 溶液 $(\mathrm{NaOH}$ で $\mathrm{pH} 7.2$ に調整) を入れ，この中 に分極・未分極ペレットを浸漬させた. ペレットは，空気と 水溶液の界面での均一核形成により生成した微小結晶が基板 上に付着することを避けるために，溶液中につるした，PAA を添加する場合はあらかじめ $\mathrm{CaCl}_{2}$ 溶液に加えた. $\left(\mathrm{NH}_{4}\right)_{2} \mathrm{CO}_{3}$ からの $\mathrm{CO}_{2}$ vaporを調整し，これを $\mathrm{CaCl}_{2}$ 溶液に拡散させるこ とで $\mathrm{CaCO}_{3}$ の結晶化を行った. 固体 $\left(\mathrm{NH}_{4}\right)_{2} \mathrm{CO}_{3}$ からの $\mathrm{CO}_{2}$ と $\mathrm{NH}_{3}$ が拡散することにより $\mathrm{CaCO}_{3}$ の形成による反応水溶液の $\mathrm{pH}$ の滅少を抑制し，最終的には反応水溶液の $\mathrm{pH}$ はアンモニ ウムー水酸化アンモニウム緩衝液の $\mathrm{pH}$ である 9.4 になる.

析出した炭酸カルシウム集合体の同定と配向成長の詳細な 分析を薄膜 X線解析で行った. 分析結果から成長方向が配向 しているカルサイト結晶であることが分かった. 回折角が 200 〜 50॰ の範囲で得られたカルサイト (hk.1) の回折線強度より, その (hk.1) 面の存在割合を次の式を用いて求めた ${ }^{24)}$.

$$
\%_{\text {hk. }}=\left(\mathrm{I}_{\text {h. } .1} / \mathrm{I}_{\text {hk. } .1}^{*}\right) / \sum\left(\mathrm{I}_{\text {hk. } 1} / \mathrm{I}_{\text {hk. } .1}^{*}\right) \times 100
$$

ここで， $\mathrm{I}_{\mathrm{hk} .1}$ は形成した集合体から得られた(hk.1)面の回折線 強度, I ${ }_{\mathrm{hk} .1}$ はカルサイト結晶の標準試料から得られた(hk.l)面 の回折線強度である.まったく配向していない試料に関して, すべての $(\mathrm{hk} .1)$ の $\left(\mathrm{I}_{\mathrm{hk} .1} / \mathrm{I}_{\mathrm{hk} . \mathrm{l}}^{*}\right)$ は一定值をとる. しかし, 配向が ある場合，ある (hk.l) 面の $\left(\mathrm{I}_{\mathrm{hk} . \mathrm{l}} / \mathrm{I}_{\mathrm{hk} . \mathrm{l}}^{*}\right)$ は， その他 (hk.l) 面の增 減により変化する. $\Sigma_{\left(\mathrm{I}_{\mathrm{h} .1 .} / \mathrm{I}_{\mathrm{hk.} .}\right)^{*}}$ はカルサイトの析出量を反映

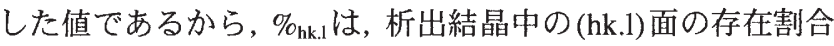
となる ${ }^{23)}$.

4.2 .1 水酸了パタイト基板上での炭酸カルシウムの結晶成長 21,227

分極処理電場の大きさと, PAAの濃度を変化させたときの $\mathrm{HAp}$ 基板上に形成した炭酸カルシウム結晶の配向結果を Table 2 に示す. 分極処理電場が $1 \mathrm{kV} \cdot \mathrm{cm}^{-1}$ の場合の蓄積電荷 量は $1.20 \mu \mathrm{C} \cdot \mathrm{cm}^{-1}, 5 \mathrm{kV} \cdot \mathrm{cm}^{-1}$ の場合は $6.02 \mu \mathrm{C} \cdot \mathrm{cm}^{-1}$ であっ た.PAAの無添加の場合, Fig.7に示すように菱面体カルサイ 卜単結晶が形成した. Fig.7より，基板に平行になっている力 ルサイトの菱形の角度を測定すると，(10.4) 面であらわ机る $104^{\circ}$ であった. Table 2に示す結晶の配向結果からこの配向成 長の出現率は分極処理の電場の大きさに比例して増大する傾 向が得られた。この事実は, 分極基板による電場がカルサイ
卜結晶の(10.4) 面が基板に平行になる配向成長を促進するこ とを示す。つまり, 表面電場は (10.4) 面の配向成長を促進す る. このことを前述の電場存在下の核形成理論加ら考察する と, 核生成の活性化工ネルギーを低下させるために, 表面工 ネルギーが最も小さい (10.4) 面が分極基板に平行に核形成さ れると理解できる。

析出した結晶の密度をTable 3に示す，0面と比較してN面 では密度が増加，P面では減少した。また， $\mathrm{N}$ 面の結晶密度 は分極処理の電場の大きさに比例し，P面では反比例するこ とが示された.これは電場の極性による基板近傍の $\mathrm{Ca}^{2+}$ イオ ンの濃度変化，すなわち，N面では炭酸カルシウムの過飽和 度が増加し，P面では滅少することを示唆している.

ポリアクリル酸 (PAA) 添加の場合, 形態は劇的に変化し, カルサイト柱状結晶による平坦な島状集合体あるいは半球状 集合体が形成した. 個々のカルサイト柱状結晶はサブミクロ ンのカルサイト結晶が互いに結合して形成されおり,これら の柱状結晶が密に接触して集合体を形成している.これら集 合体はVolmer-Weber薄膜形成過程, すなわち, 集合体の形成 $\rightarrow$ 成長・合体 $\rightarrow$ 網目構造，により薄膜へ成長した．その破断

Table 2 Percentages of (10.4) and (00.6) peaks of calcite crystals formed on non-polarized and polarized HAp ceramics with and without PAA.

\begin{tabular}{|c|c|c|c|c|}
\hline \multirow{2}{*}{ Electric field } & \multirow{2}{*}{$\begin{array}{c}\text { Amount of } \\
\text { PAA }\end{array}$} & \multirow{2}{*}{ Surface } & \multicolumn{2}{|c|}{ Crystallographic orientation } \\
\hline & & & (10.4) & $(00.6)$ \\
\hline $\mathrm{kV} \cdot \mathrm{cm}^{-1}$ & $\mathrm{mg} / 10 \mathrm{~mL}$ & - & \multicolumn{2}{|c|}{$\%_{\text {(hk.l) }}$} \\
\hline 0 & 0 & 0 & 17 & 13 \\
\hline 0 & 1 & 0 & 14 & 50 \\
\hline 0 & 2 & 0 & 12 & 54 \\
\hline 0 & 3 & 0 & 8 & 59 \\
\hline 0 & 5 & 0 & 8 & 64 \\
\hline 1 & 0 & $\mathrm{~N}$ & 41 & 8 \\
\hline 1 & 0 & $\mathrm{P}$ & 38 & 7 \\
\hline 1 & 1 & $\mathrm{~N}$ & 25 & 26 \\
\hline 1 & 1 & $\mathrm{P}$ & 24 & 25 \\
\hline 1 & 2 & $\mathrm{~N}$ & 22 & 35 \\
\hline 1 & 2 & $\mathrm{P}$ & 26 & 29 \\
\hline 1 & 3 & $\mathrm{~N}$ & 10 & 50 \\
\hline 1 & 3 & $\mathrm{P}$ & 13 & 46 \\
\hline 1 & 5 & $\mathrm{~N}$ & 19 & 54 \\
\hline 1 & 5 & $\mathrm{P}$ & 21 & 41 \\
\hline 5 & 0 & $\mathrm{~N}$ & 64 & 0 \\
\hline 5 & 0 & $\mathrm{P}$ & 60 & 0 \\
\hline 5 & 1 & $\mathrm{~N}$ & 19 & 51 \\
\hline 5 & 1 & $\mathrm{P}$ & 25 & 38 \\
\hline 5 & 2 & $\mathrm{~N}$ & 18 & 56 \\
\hline 5 & 2 & $\mathrm{P}$ & 21 & 40 \\
\hline 5 & 3 & $\mathrm{~N}$ & 6 & 66 \\
\hline 5 & 3 & $\mathrm{P}$ & 14 & 46 \\
\hline 5 & 5 & $\mathrm{~N}$ & 3 & 87 \\
\hline 5 & 5 & $P$ & 9 & 71 \\
\hline
\end{tabular}



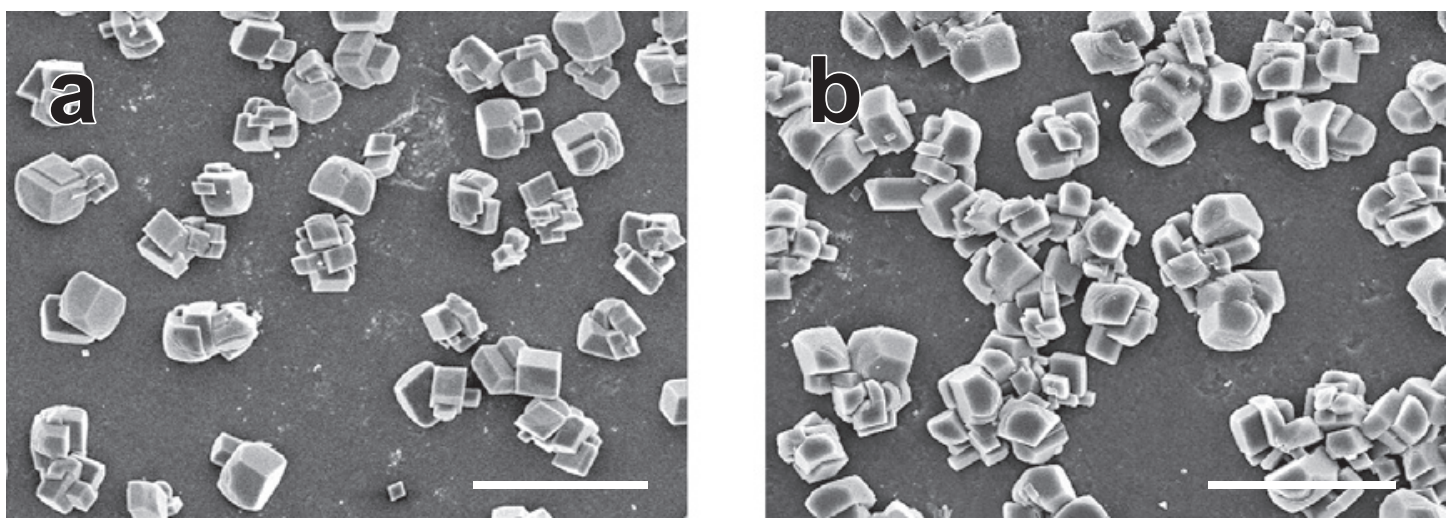

Fig.7 Scanning electron micrographs of calcite crystals formed on 0 - and $\mathrm{N}$-surfaces. (a), calcite crystals formed on 0 -surface. (b), calcite crystals formed on $\mathrm{N}$-surface polarized by $5 \mathrm{kVcm}^{-1}$ without PAA. In (b), the (10.4) faces are indicated by an open arrow. Scale bars $=50 \mu \mathrm{m}$.

Table 3 Crystal density of calcite formed $0, \mathrm{~N}$, and P surfaces without PAA.

\begin{tabular}{ccc}
\hline Electric field $\left(\mathrm{vcm}^{-1}\right)$ & Surface & Crystal density $\left(\mathrm{cm}^{-2}\right)$ \\
\hline 0 & 0 & $3.0 \times 10^{5}$ \\
20 & $\mathrm{~N}$ & $2.3 \times 10^{6}$ \\
20 & $\mathrm{P}$ & $1.8 \times 10^{5}$ \\
\hline
\end{tabular}

面はカルサイト柱状晶による貝殼類似構造あるいは扇型構造 を示した. 電場とPAAの協調作用はカルサイトの薄膜形成を 促進し, 薄膜の強度を増加させた. さらにこの協調作用はN面 で顕著に発揮された。

$\mathrm{N}$ 面上で形成した薄膜は平坦な表面を有していた.PAAの 添加量が $2 \mathrm{mg}$ 以下では, 破断面が貝殼類似構造を持つ膜厚が $4 \sim 10 \mu \mathrm{m}$ の薄膜が分極基板全体に形成した. 薄膜は, 基板に 平行な 3 回対称の三角形の $(00.1)$ 面を先端とし, c 軸を成長方 向としたカルサイト柱状結晶の集合体で構成されていた (Fig.8 (a), (b)). 一方, PAAの添加量が $3 \mathrm{mg}$ 以上では, 破断面 が扇型構造を持つ膜擪が $3 \sim 7 \mu \mathrm{m}$ の薄膜が分極基板全体に形 成した。薄膜は，(10.4) 面で囲まれた三角錐の先端を持った カルサイト柱状晶 (成長方向が $\mathrm{c}$ 軸)の半球状集合体で構成さ れていた。

$\mathrm{P}$ 面上で形成した薄膜は凹凸のある表面を有していた. $\mathrm{PAA}$ の添加量が $2 \mathrm{mg}$ 以下の場合, $1 \mathrm{kV} \cdot \mathrm{cm}^{-1}$ での分極処理で は，(10.4) 面で囲まれた三角錐の先端を持ったカルサイト柱 状晶 (成長方向がc軸)による半球状集合体で構成された, 破 断面が扇型構造を持つ膜厚が $2 \sim 4 \mu \mathrm{m}$ の薄膜が基板全体を 覆つた (Fig.8 (c), (d)). $5 \mathrm{kV} \cdot \mathrm{cm}^{-1}$ で分極処理した際は同様な 構造を持つ部分膜が形成した。一方, PAAの添加量が $3 \mathrm{mg}$ 以上の場合, 1 ならびに $5 \mathrm{kV} \cdot \mathrm{cm}^{-1} て ゙$ 分極処理した基板上では 上述した $\mathrm{AA}$ の添加量が $2 \mathrm{mg}$ 以下の場合と同様な形態と構造 を持つ膜厚が $3 \sim 6 \mu \mathrm{m}$ の薄膜が基板全体を覆つた.

0面上では, (10.4)面で囲まれた三角錐の先端を持ったカル サイト柱状晶 (成長方向がc軸)による破断面が見られ, 扇型 構造を持つ部分膜が形成した (Fig.8 (e), (f)).
PAAの添加量を一定にした実験において, 奏験終了後の薄 膜の膜厚は $\mathrm{P}$ 面上よりも $\mathrm{N}$ 面上で厚かった。この事実は $\mathrm{N}$ 面 上でのカルサイト結晶の成長速度がP面上のものより大きい ということを反映している.この現象はすでに述べたHApの 結晶成長の結果と一致し, $\mathrm{N}$ 面による表面電場が反応溶液中 の $\mathrm{Ca}^{2+}$ イオンを引きつけ, その近傍で $\mathrm{CaCO}_{3}$ の高い過飽和状 態を形成することから説明できる.

PAAの添加量と配向方向に着目する. カルサイト集合体か ら得られた X 線回折に (10.4) 面と (00.6) 面に相当する二つの 強いピークがみられ, かつPAAの添加量に依存してその強度 に変化が見られた. 各実験条件で得られた試料について,こ の二つの面の存在比を求めた結果がTable 2 に示されている. 分極処理電場の大きさを一定にしたとき, PAAの添加量が大 きくなるにしたがって (00.6)面の存在比が増加し, (10.4)面の 存在比が減少した。すなわち, PAAの添加量は(00.1) 配向成 長を促進した.

PAA 存在下での薄膜の形成過程について以下に述べる. 高 分子添加物であるPAA(分子量 2000) の解離定数 (pK) は 4.5 で あるため, 反応水溶液の $\mathrm{pH}$ が 7.2 9.4で PAAの力ルボキシ ル基の多くは-COO-の形になっている. そのため水溶液中の 一部の $\mathrm{Ca}^{2+}$ イオンは PAA-Ca ${ }^{2+}$ 錯体を形成する. この際, PAA$\mathrm{Ca}^{2+}$ 錯体は部分的に帯電状態を示す.この錯体中で-COO- 基 の間隔は $0.502 \mathrm{~nm}$ であり,この間隔はカルサイト $(00.1)$ 面の Ca サイトの間隔である $0.499 \mathrm{~nm}$ にほぼ一致する.このため, カルサイトの結晶化の初期段階において, 分極・未分極基板 上に $\mathrm{CaCl}_{2}$ 溶液中で形成した不安定な帯電部位を持つ PAA$\mathrm{Ca}^{2+}$ 錯体集合体が吸着し，カルサイト $(00.1)$ 面がその錯体に 平行に配向して成長するカルサイト結晶の鋳型となる. その 結果, $\mathrm{c}$ 軸配向のカルサイト結晶が成長する. その際, PAA$\mathrm{Ca}^{2+}$ 錯体集合体の形態は分極基板による表面電場の特性，お よび PAA-Ca $\mathrm{Ca}^{2+}$ 錯体の帯電分布によりその構造が伸長様態あ るいは半球様態をとると考えると, 破断面の構造を合理的に 説明できる. N面 (PAA 添加量 $2 \mathrm{mg}$ 以下) では伸長様態のPAA$\mathrm{Ca}^{2+}$ 錯体集合体を鋳型とし, 基板に垂直方向を $\mathrm{c}$ 軸としたカ 

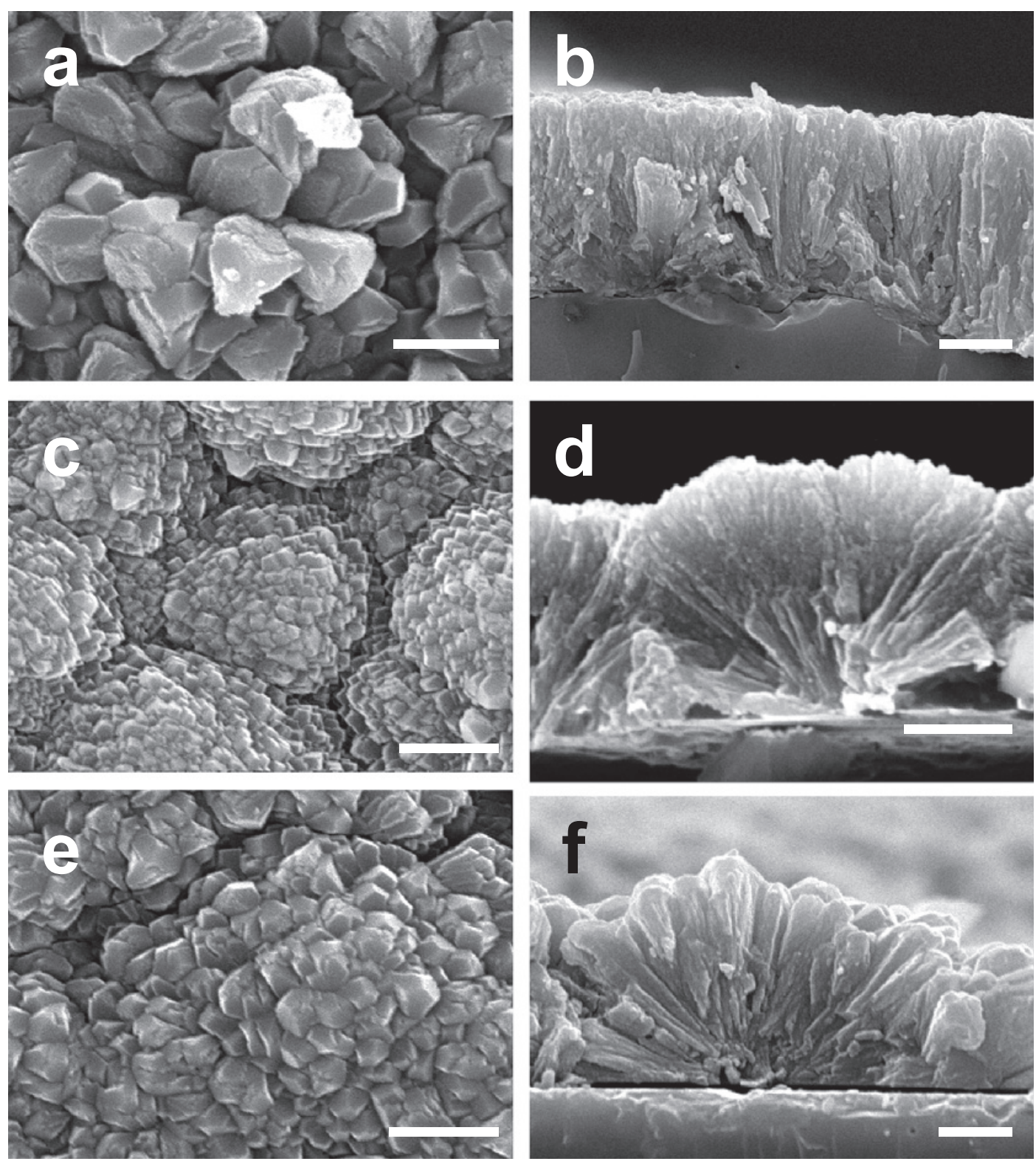

Fig.8 Scanning electron micrographs of the surface morphology (a, c, e) and fracture $(b, d, f)$ of calcite thin films formed on N-, P-and 0 -surfaces. ( $\mathrm{a}, \mathrm{b}$ ), $\mathrm{N}$-surface polarized by $5 \mathrm{kVcm}^{-1}$ and $2 \mathrm{mg}$ PAA addition. (c, d), P-surface polarized by $5 \mathrm{kVcm}^{-1}$ and $2 \mathrm{mg} \mathrm{PAA}$ addition. (e, f), 0 -surface and $5 \mathrm{mg}$ PAA addition. Scale bars $=1 \mu \mathrm{m}$.

ルサイト柱状晶が成長し, 貝殼類似構造の破断面を持つ薄膜 が形成する.これ以外の実験条件下で形成した破断面が扇構 造を持つカルサイト薄膜またはカルサイト集合体は, 半球様 態のPAA-Ca ${ }^{2+}$ 錯体集合体から放射状にc軸を成長方向として カルサイト柱状晶が成長して形成する。一方, 水溶液中に浮 遊しているPAA と PAA-Ca ${ }^{2+}$ 錯体は，表面エネルギ一が大き いカルサイト (00.1) 面に吸着することにより, その表面エネ ルギーを減少させ, カルサイト $(00.1)$ 面を安定させる.

以上まとめると, エレクトロベクトル効果は $\mathrm{Ca}^{2+}$ イオンの 輸送を制御し, また, カルサイト (10.4) 面の配向成長を促進 する、さらに, PAAを添加することにより, $\mathrm{PAA}-\mathrm{Ca}^{2+}$ 錯体 の帯電分布を通じて結晶成長形態を制御できる.
4.2.2 イットリア安定化ジルコニア基板上で炭酸カルシウムの 結晶成長 ${ }^{23)}$

分極処理電場 $20 \mathrm{~V} \cdot \mathrm{cm}^{-1}$ にて分極した YSZ 基板 (蓄積電荷 量 $1.0 \mathrm{mC} \cdot \mathrm{cm}^{-1}$ ) 上と未分極 YSZ 基板上に PAA の添加・無添 加により形成したカルサイト結晶について，X線回折分析よ り求めた配向性および $\Sigma\left(\mathrm{I}_{\mathrm{hk} . \mathrm{l}} \mathrm{I}^{*}{ }_{\mathrm{hk} . \mathrm{l}}\right)$ の結果を Table 4 に示す. HAp基板上のカルサイト結晶成長実験と同様な結果が得られ た. PAAの無添加の場合, 菱面体力ルサイト単結晶が形成し (Fig.9), 分極基板上では, カルサイト結晶の (10.4) 面が基板 に平行になる配向成長が促進されることが示された. 析出し た結晶の密度をTable 5 に示す. 0 面と比較してN面では密度 が増加, P面では減少した。 また, この結果はHAp 基板で得 
Table 4 Percentages of (10.4) and (00.6) peaks and $\sum\left(\mathrm{I}_{\mathrm{hk.l}} / \mathrm{I}^{*}{ }_{\mathrm{hk} . \mathrm{l}}\right)$ of calcite crystals formed on non-polarized and polarized YSZ ceramics with and without PAA.

\begin{tabular}{|c|c|c|c|c|}
\hline \multirow{2}{*}{$\begin{array}{c}\text { Amount of } \\
\text { PAA }\end{array}$} & \multirow[t]{2}{*}{ Surface } & \multicolumn{2}{|c|}{$\begin{array}{l}\text { Crystallographic } \\
\text { orientation }\end{array}$} & \multirow[t]{2}{*}{$\sum\left(I_{\text {nk. } .1} / I_{\text {hk. } .1}^{*}\right)$} \\
\hline & & $(10.4)$ & $(00.6)$ & \\
\hline $\mathrm{mg} / 10 \mathrm{ml}$ & - & \multicolumn{2}{|c|}{$\%$} & - \\
\hline 0 & 0 & 17 & 13 & $3.2 \times 10^{3}$ \\
\hline 0 & $N$ & 41 & 8 & $4.2 \times 10^{3}$ \\
\hline 0 & $\mathrm{P}$ & 38 & 7 & $2.4 \times 10^{3}$ \\
\hline 2 & 0 & 12 & 37 & $4.3 \times 10^{3}$ \\
\hline 2 & $\mathrm{~N}$ & 28 & 50 & $5.1 \times 10^{3}$ \\
\hline 2 & $P$ & 23 & 44 & $4.0 \times 10^{3}$ \\
\hline 4 & 0 & 11 & 51 & $6.0 \times 10^{3}$ \\
\hline 4 & $\mathrm{~N}$ & 13 & 54 & $7.4 \times 10^{3}$ \\
\hline 4 & $\mathbf{P}$ & 19 & 47 & $3.0 \times 10^{3}$ \\
\hline 8 & 0 & 12 & 61 & $2.0 \times 10^{5}$ \\
\hline 8 & $\mathrm{~N}$ & 7 & 73 & $2.2 \times 10^{5}$ \\
\hline 8 & $\mathbf{P}$ & 7 & 63 & $1.8 \times 10^{5}$ \\
\hline 10 & 0 & 12 & 32 & $4.7 \times 10^{4}$ \\
\hline 10 & $\mathrm{~N}$ & 12 & 37 & $5.6 \times 10^{4}$ \\
\hline 10 & $\mathrm{P}$ & 14 & 34 & $3.7 \times 10^{4}$ \\
\hline
\end{tabular}
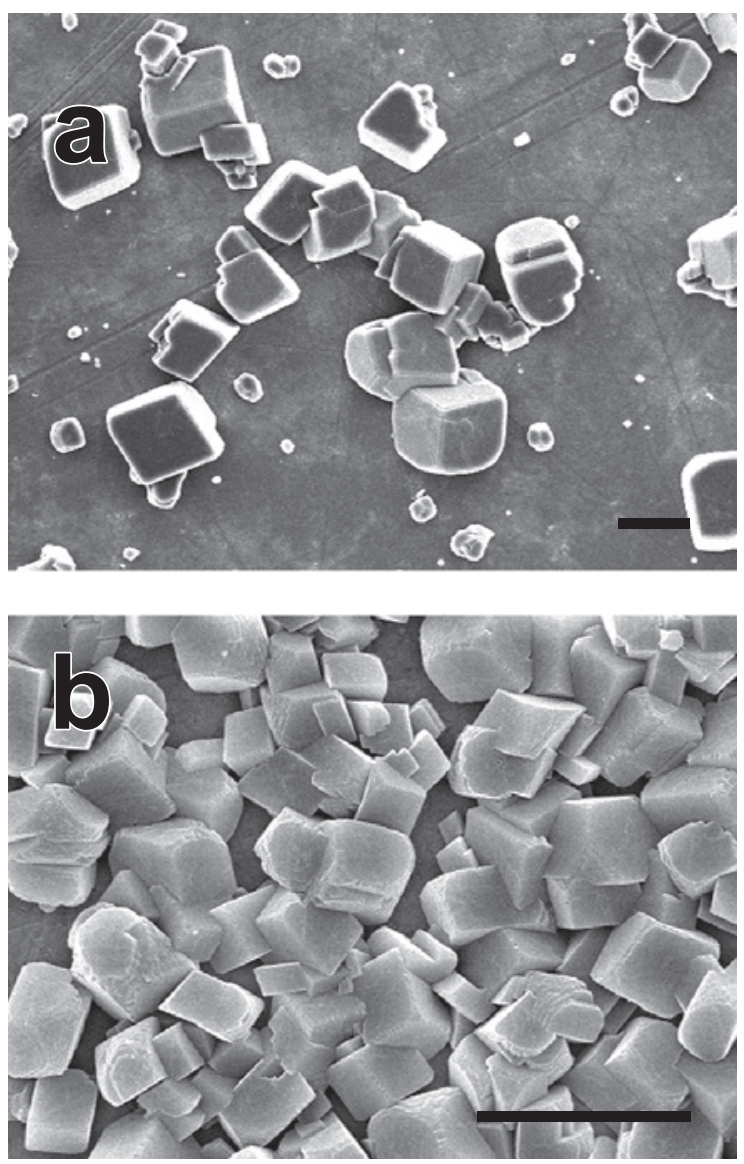

Fig.9 Scanning electron micrographs of calcite crystals formed on 0 - and $\mathrm{N}$-surfaces without PAA: (a) 0-surface; (b) $\mathrm{N}$ surface. Scale bar $=2 \mu \mathrm{m}$.
Table 5 Crystal density of calcite formed on $0_{-}^{-}, \mathrm{N}$ - and $\mathrm{P}$-surfaces without PAA.

\begin{tabular}{ccc}
\hline $\begin{array}{c}\text { Electric Field } \\
\left(\mathrm{kVcm}^{-1}\right)\end{array}$ & Surface & Density $\left(\mathrm{cm}^{-2}\right)$ \\
\hline 0 & 0 & $7.0 \times 10^{4}$ \\
1 & $\mathrm{~N}$ & $7.8 \times 10^{4}$ \\
1 & $\mathrm{P}$ & $6.5 \times 10^{4}$ \\
5 & $\mathrm{~N}$ & $9.8 \times 10^{4}$ \\
5 & $\mathrm{P}$ & $5.6 \times 10^{4}$ \\
\hline
\end{tabular}

られた結晶の密度と比較すると，1析大きい。これはYSZ基 板の蓄積電荷量が大きいことに関係していると考える. PAA を添加した場合, HApでの実験結果と同様に, c 軸配向の力 ルサイト柱状晶集合体による破断面が扇構造を持つ薄膜 (Volmer-Weber mode)が形成した (Fig.10). c 軸配向はPAA 添加量が増加するに従って促進され，N面の方がP面よりそ の傾向は顕著であった. カルサイトの析出量を反映している $\Sigma\left(\mathrm{I}_{\mathrm{hk} . \mathrm{l}} / \mathrm{I}_{\mathrm{hk} .1}^{*}\right)$ は, 添加量に比例して増加し, PAA の添加量が $8 \mathrm{mg}$ のとき最大となった. P面, $\mathrm{N}$ 面および 0 面上に析出した カルサイトの析出量は $\mathrm{N}$ 面 $>0$ 面 $>\mathrm{P}$ 面の関係である. PAAの 添加量が $8 \mathrm{mg}$ の場合の薄膜の厚さは $5.0 \mu \mathrm{m}$ であった. 一方, 添加量が $10 \mathrm{mg}$ の場合, カルサイトの $\mathrm{c}$ 軸配向の割合および その析出量は減少した. 形成した薄膜は, 混在する三角形の (00.1)面を先端とし, c軸を成長方向としたカルサイト柱状結 晶の集合体と(10.4) 面で囲まれた三角錐の先端を持ったカル サイト柱状晶 (成長方向が c 軸) の集合体で構成されていた. $\mathrm{HAp}$ 基板上で形成した破断面が貝殼類似構造の薄膜は, YSZ 基板上では形成しなかった. カルサイトの結晶成長における HAp 基板とYSZ基板での異なる結果は, 結晶析出における工 レクトロベクトル効果の違いが原因であると考えられる.す なわち, HAp 基板とYSZ基板では, 表面電場の大きさが異な り,さらに, HApが水酸化物でYSZが酸化物であることから 表面特性が異なる.この表面電場と表面特性に起因して, カ ルサイト結晶の鋳型になる PAA-Ca ${ }^{2+}$ 錯体集合体の構造とそ の部分的な帯電分布状態が HAp 基板上と YSZ 基板上では異 なる之考えられる.この差異によって, 結晶析出の様態の基 板種類による差が生じるものと考察できる.

\section{5 結言}

本稿では, ベクトルマテリアルのコンセプトとその応用に ついて紹介した. 特に, エレクトロベクトル効果，すなわち， エレクトレットの生成する静電場が周辺物質に影響を与える 例を紹介した，生体内における例として，HApエレクトレッ トによる骨再生能の向上効果を紹介した，また，結晶成長に おけるエレクトロベクトル効果について, 理論とHApłよび カルサイトの結晶成長実験の結果について論述した. カルサ イト結晶成長実験から得られた知見は, 表面電場により, 結 晶の多形とその集合体の構造を制御できることを指摘する. 

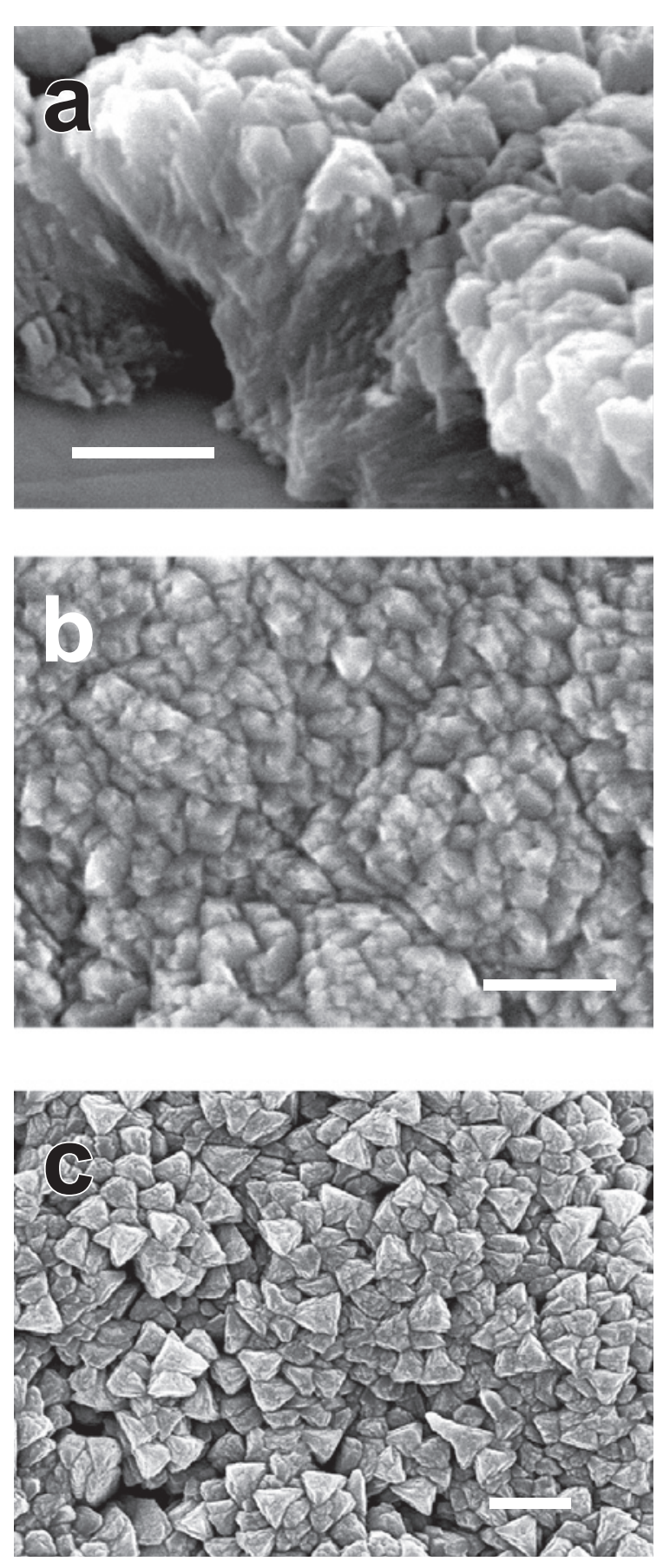

Fig.10 Scanning electron micrographs of the surface and fracture morphologies of calcite thin films formed on $\mathrm{N}$-surface in the presence of $2 \mathrm{mg}$ PAA: (a) fracture; (b) calcite needles capped with the rhombohedra (10.4) planes; (c) calcite needles with the top of (00.1) planes. Scale bar $=1 \mu \mathrm{m}$.

さらに, 高分子添加物の種類と濃度を調整することで, 多彩 な構造を持つ結晶集合体の形成も期待できる. 以上示したよ うに, エレクトロベクトル効果は生体活動の制御および結晶 成長の制御に新たな切り口を提供できる. ベクトルマテリア ルの概念が, 新しい材料科学の発展に貢献できると期待して いる.

\section{文献}

1) K. Yamashita and S. Nakamura: "Concept and Development of Vector Ceramics for Bio-interface Engineering", J. Ceram. Soc. Jpn., 113(2005) 1-9.

2) S. Nakamura, T. Kobayashi, and K. Yamashita: "Extended bioactivity in the proximity of hydroxyapatite ceramic surfaces induced by polarization charges", J. Biomed. Mater. Res., 61 (2002) 593-599

3) S. Itoh, S. Nakamura, M. Nakamura, K. Shinomiya, and K. Yamashita: "Enhanced bone ingrowth into hydroxyapatite with interconnected pores by Electrical Polarization", Biomaterials, 27(2006)5572-5579.

4) S. Nakamura, T. Kobayashi, M. Nakamura, and K. Yamashita: "Enhanced in vivo responses of osteoblasts in electrostatically activated zones by hydroxyapatite electrets", J. Mater. Sci. Mater. Med., 20(2009)99-103.

5) S. Nakamura, T. Kobayashi, M. Nakamura, S. Itoh, and K. Yamashita: "Electrostatic surface charge acceleration of bone ingrowth of porous hydroxyapatite/ $\beta$-tricalcium phosphate ceramics", J. Biomed. Mater. Res. Part A, 92A(2010) 267-275.

6) D. Kumara, J.P. Gittingsb, I.G. Turnerb, C.R. Bowenb, A. Bastida-Hidalgoa, and S.H. Cartmella: "Polarization of hydroxyapatite: Influence on osteoblast cell proliferation", Acta Biomaterialia, 6(2010) 1549-1554.

7) Klein CPAT, de Blieck-Hogervorst JMA, Wolke JGC, de Groot $\mathrm{K}$ : "Studies of the solubility of different calcium phosphate ceramic particles in vitro", Biomaterials, 11(1990)509-512 .

8) Koerten HK, van der Meulen J: "Degradation of calcium phosphate ceramics", J. Biomed. Mater. Res., 44(1999)78-86.

9) K. Yamashita, K. Kitagaki, and T. Umegaki: "Thermal Instability and Proton Conductivity of Ceramic Hydroxyapatite at High Temperatures", J. Am. Ceram. Soc., 78(1995)11911197.

10) K. Yamashita, H. Owada, H. Nakagawa, T. Umegaki, and T. Kanazawa: "Trivalent-Cation-Substituted Calcium Oxyhydroxyapatite", J. Am. Ceram. Soc., 69(1986)590-594.

11) M. Ueshima, S. Nakamura, M. Ohgaki, and K. Yamashita: "Electrovectorial Effect of Polarized Hydroxyapatite on QuasiEpitaxial Growth at Nano-Interfaces", Solid State Ionics, 151 (2002)29-34.

12) R. Dhanasekaran and P. Ramasamy: "Two-dimensional Nucleation in the Presence of an Electric Field", J. Crystal Growth, 79(1986)993-996.

13) M. Nakamura, A. Nagai, T. Hentunen, J. Salonen, Y. Sekijima, T. Okura, K. Hashimoto, Y. Toda, H. Monma, and K. Yamashita: "Surface Electric Fields Increase Osteoblast Adhesion through Improved Wettability on Hydroxyapatite Electrets", ACS Appl. Mater, Interfaces, 1(2009)2181-2189. 
14) K. Yamashita, N. Oikawa, and T. Umegaki, "Acceleration and Deceleration of Bone-Like Crystal Growth on Ceramic Hydroxyapatite by Electric Poling", Chem. Mater., 8(1996) 2697-2700.

15) T. Iwasaki, Y. Tanaka, M. Nakamura, A. Nagai, K. Hashimoto, Y. Toda, K. Katayama, and K. Yamashita: "Rate of Bone like Apatite Formation Accelerated on Polarized Porous Hydroxyapatite", J. Am. Ceram. Soc., 91(2009)3943-3949.

16) P.C. Pieke: "Selection of Phase and Control of Orientation during Physisorption on Surfaces of Homogeneously Formed Calcium Carbonate Nuclei", Mater. Sci. Eng., C2(1995) 181 189.

17) A. Sugawara, T. Ishii, and T. Kato, "Self-Organized Calcium Carbonate with Regular Surface-Relief Structures", Angew. Chem. Int. Ed., 42(2003)5299-5303.

18) N. Wada, S. Suda, K. Kanamura, and T. Umegaki: "Formation of Thin Calcium Carbonate Films with Aragonite and Vaterite Forms Coexisting with Polyacrylic Acids and Chitosan Membranes", J. Colloid Interface Sci., 279(2004) 167-174.

19) A. Kotachi, T. Miura, and H. Imai: "Morphological Evaluation and Film Formation with Iso-Oriented Calcite Crystals Using Binary Poly(Acrylic Acid)", Chem. Mater., 16(2004) 3191 -
3196.

20) X. Xu, J.K. Han, and K. Cho: "Deposition of Amorphous Calcium Carbonate Hemispheres on Substrates", Langmuir, 21 (2005)4801-4804.

21 N. Wada, M. Nakamura, T. Hiyama, A. Nagai, and K. Yamashita: "Controlled Deposition of Calcite Crystals on Yttria-Stabilized Zirconia Ceramic Electrets", Cryst. Growth Des., 11(2011)166174.

22) N. Wada, Y. Tanaka, M. Nakamura, K. Kanamura, and K. Yamashita: "Controlled Crystallization of Calcite Under Surface Electric Field Due to Polarized Hydroxyapatite Ceramics", J. Am. Ceram. Soc., 92(2009) 1586-1591.

23) N. Wada, M. Nakamura, Y. Tanaka, K. Kanamura, and K. Yamashita: "Formation of Calcite Thin Films by Cooperation of Polyacrylic Acid and Self-generating Electric Field Due to Aligned Dipoles of Polarized Substrates", J. Colloid Interface Sci., 330(2009)374-379.

24) J. Aizenberg, A.J. Black, and G.M. Whitesides: "Oriented Growth of Calcite Controlled by Self-Assembled Monolayers of Functionalized Alkanethiols Supported on Gold and Silver", J. Am. Chem. Soc., 121(1999)4500-4509. 